\title{
FIRST REPORT OF Cucumis melo endornavirus WITH A NEW HOST, THE GHERKIN (Cucumis anguria Linn.), IN TURKEY
}

\author{
Ali KARANFIL", Savaş KORKMAZ \\ Çanakkale Onsekiz Mart University, Faculty of Agriculture, Department of Plant Protection, 17100, Çanakkale, TURKEY \\ Cite this article as: \\ Karanfil A., Korkmaz S. 2020. First Report of Cucumis melo endornavirus with a New Host, the Gherkin (Cucumis anguria Linn.), in Turkey. Trakya \\ Univ J Nat Sci, 21(1): 63-67, DOI: 10.23902/trkjnat.688646
}

Received: 13 February 2020, Accepted: 11 April 2020, Published: 15 April 2020

Edited by:

Yildız Aydın

*Corresponding Author:

Ali Karanfil

ali.karanfil@hotmail.com

\section{ORCID ID:}

orcid.org/0000-0002-4503-6344

Key words:

Melon

Gherkin

Virus

CmEV

\begin{abstract}
More than 50 viruses causing infection in members of the family Cucurbitaceae have been identified in the world so far. Because of the development of virus detection methods, new viruses are added to the known infectious cases list every day. One of the viruses recently identified is the Cucumis melo endornavirus $(\mathrm{CmEV})$ which has been reported from different countries all over the world. However, no study for determination of $\mathrm{CmEV}$ has been done so far in Turkey. For the purpose of this study, 59 cucurbit plants showing virus and virus-like symptoms were collected from Manisa and İzmir provinces in Turkey. The samples were tested, for presence of CmEV, by reverse-transcriptase polymerase chain reaction and $\mathrm{CmEV}$ infections were detected in 47 samples, of which 44 were melon (Cucumis melo Linn.), and the remaining were gherkins $(C$. anguria Linn.). Among the infected samples, five samples (three were melon, and two were gherkin) were chosen for sequence analysis. After evaluating the sequence analysis results, it was shown that the Turkish isolates presented 93\%-99\% and 93\%-98\% identities at the nucleotide level and $94 \%-99 \%$ and $91 \%-98 \%$ identities at the amino acid level among each other and worldwide isolates, respectively. To the best of our knowledge, this is the first report of $\mathrm{CmEV}$ in gherkin as a new host both in Turkey and worldwide.
\end{abstract}

Özet: Dünyada gerçekleştirilen çalışmalar sonucunda kabakgil familyasındaki bitkileri enfekte eden 50'den fazla virüs varlığı tanımlanmıştır. Virüs tespit metotlarındaki gelişmelere bağlı olarak bu sayıya her geçen gün yenileri eklenmektedir. Son yıllarda tanılanan bu virüs hastalıklarından bir tanesi de Cucumis melo endornavirus (CmEV)'dır. CmEV'nin enfeksiyonu dünyanın farklı ülkelerinden bildirilmiştir. Ancak, ülkemizde şimdiye kadar CmEV varlığının belirlenmesine yönelik bir çalışma gerçekleştirilmemiştir. Bu amaçla, Manisa ve İzmir illerinden virüs ve virüsbenzeri belirti gösteren 59 kabakgil bitkisinden örnekler alınmıștır. Toplanan örnekler ters transkriptaz-polimeraz zincir reaksiyonu ile test edilmiştir. Gerçekleştirilen bu testler sonucunda 47 örnekte CmEV enfeksiyonu tespit edilmiştir. Enfekteli 47 örneğin 44 tanesi kavun (Cucumis melo Linn.), kalan 3 örnek ise acurdur ( $C$. anguria Linn.). Enfekteli örnekler arasından, beş tanesi (üç tanesi kavun, iki tanesi acur) sekans analizleri için seçilmiştir. Gerçekleştirilen sekans analizleri sonucunda CmEV izolatları kendi aralarında nükleotit düzeyinde \%93-99, amino asit düzeyinde ise \%94-99 benzerlikler gösterdiği belirlenmiştir. Dünya izolatları ile yapılan benzerlik analizleri sonucunda ise nükleotit düzeyinde \%93-98, amino asit düzeyinde ise \%91-98 benzerlikler tespit edilmiştir. Gerçekleştirilen bu çalışma ile ülkemizde ilk kez CmEV enfeksiyonu kavun ve dünya için yeni bir konukçu kaydı olan acur bitkisinde tespit edilmiştir.

\section{Introduction}

Turkey is characterized with a wide range of ecological diversity which allows cultivation of different plant taxa one of which includes the cucurbit plants in the family Cucurbitacea (Çat et al. 2016). The currently known 825 species of this family are placed in 118 genera (Jeffrey 1980). The most important species of this family include melon (Cucumis melo Linn.), watermelon (Citrullus lanatus Thumb.), gherkin (Cucumis anguria Linn.), and zucchini/squash/pumpkin (Cucurbita spp.) all which can be cultivated in almost every region of the world and provide important economic inputs to their producers.

There are many viral diseases known to affect members of this important plant family (Zitter et al. 1996) by causing economic losses. New viruses are increasingly being added to the list of disease agents and they threaten the production of cucurbit plants. Some of these viruses are routinely studied, while others are not. Therefore, there is no reliable available information about the importance and prevalence of these viruses. 
A number of viruses infecting cucurbit plants in Turkey were identified (Köklü \& Yilmaz 2006, Ozaslan et al. 2006, Kamberoglu et al. 2016), among which the most prevalent viruses are the Watermelon mosaic virus, Cucumber mosaic virus, and the Zucchini yellow mosaic virus (Kaya \& Erkan 2011, Keçe \& Kamberoğlu 2016, Topkaya et al. 2019).

Cucumis melo endornavirus $(\mathrm{CmEV})$ is one of the recently identified viral disease agent infecting the cucurbit plants. $\mathrm{CmEV}$ is a member of the endornavirus family that infects plants and fungi. The causal agent has (+)ssRNA genome containing nucleotides of around 15 kb (Valverde et al. 2019).

The presence of $\mathrm{CMeV}$ has so far been reported only from Ecuador, USA and Brazil (Quito-Avila et al. 2014, Sabanadzovic et al. 2016, da Costa et al. 2019). Based on a Japanese study, it was shown that dsRNA bands close to the CmEV genome were obtained from melon via dsRNA analysis (Fukuhara et al. 2006). CmEV sequences from South Korea are available in the GenBank. However, there has been no attempt in Turkey so far to detect the presence of $\mathrm{CmEV}$ infection. In the present study, field studies were performed on cucurbit plants grown in Manisa and İzmir provinces on Turkey and the presence of the $\mathrm{CmEV}$ as the causal agent was investigated.

\section{Materials and Methods}

\section{Sampling and virus detection}

Samples were collected in randomly selected fields in İzmir and Manisa provinces among cucurbit plants only showing the virus and virus-like symptoms (Fig. 1). The field studies were carried out from June to September in 2019. When similar symptoms were observed in the same field, only three samples were collected.

The presence of $\mathrm{CmEV}$ in the collected samples was determined by reverse-transcriptase polymerase chain reaction (RT-PCR) using a virus-specific primer pair. Before performing RT-PCR, total nucleic acid (TNA) isolation was performed by the cetyl trimethylammonium bromide (CTAB) method (Li et al. 2008). The resulting TNAs were checked by agarose gel electrophoresis and stored at $-80^{\circ} \mathrm{C}$ until used.

To determine the presence of $\mathrm{CmEV}$ in the resulting TNAs, complementary DNAs (cDNAs) were initially synthesized using the RevertAid First Strand cDNA Synthesis Kit (Thermo Scientific TM, USA). The presence of $\mathrm{CmEV}$ was then screened by PCR with the CmEVprimer pair (Table 1) specific to the partial polyprotein gene. PCR tests were performed according to conditions as indicated by Quito-Avila et al. (2014) using 2X EmeraldAmp® Max PCR Master Mix (Takara, Japan).

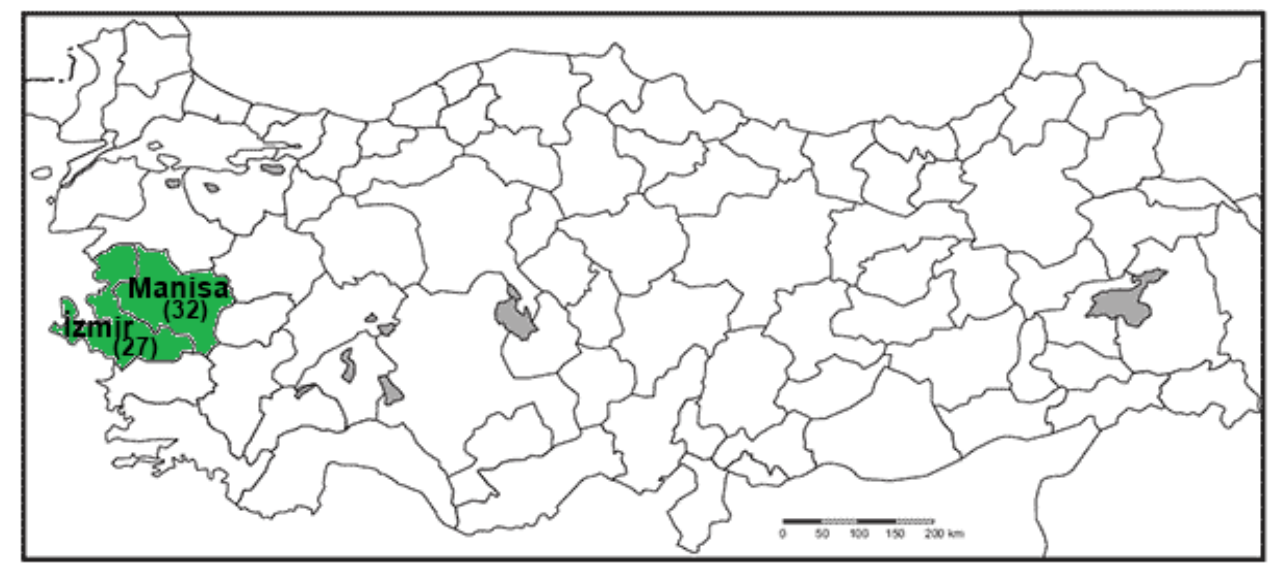

Fig. 1. Map showing the provincial borders of the two provinces (shaded in green) in the western part of Turkey where the field samplings were performed. The numbers in parentheses correspond to the sampling numbers in each province.

\section{Sequence analysis}

Five samples were chosen among the samples which were accepted to be infected with CmEV based on host species and the geographic origin, where they were obtained from. The resulting RT-PCR products were purified by EZ-10 Spin Column PCR Products (BioBasic, Canada) and sequenced bilaterally.
The assembled sequences were used to match with other world $\mathrm{CmEV}$ isolates from the GenBank (Table 2). Sequence identities of the isolates were determined with the sequence Demarcation Tool V. 1.2 (Muhire et al. 2014). The phylogenetic relationship was determined in CLC Main Work Bench V. 20 packet program (Qiagen, Canada) using the neighbor-joining method by applying Kimura 2-parameter with 1000 bootstrap replications.

Table 1. Primer pair used in RT-PCR for determination of CmEV infection in the collected samples.

\begin{tabular}{ccccc}
\hline \hline Primer code & Primer sequence (5'-3') & Sense & Fragment size & Reference \\
\hline \hline CmEVF & GGTGGAATATGGGTTGATGCTAG & Forward & \multirow{2}{*}{$413 \mathrm{bp}$} & Quito-Avila et al. (2014) \\
CmEVR & CGTCGTGATGGACATCAACTCTAC & Reverse & & \\
\hline \hline
\end{tabular}


Table 2. CmEV isolates used in molecular characterization studies

\begin{tabular}{lllll}
\hline \hline Isolate Code & Accession Number & Host & Origin & Reference \\
\hline \hline SJ1 & KX641269 & Korean melon & South Korea & Baek et al. (2016) \\
CL-01 & NC_029064 & Melon & USA & Sabanadzovic et al. (2016) \\
BRA/TO-74/2010 & MH365459 & Not known* & Brazil & da et al. $(2019)$ \\
BRA/TO-23/2014 & MH365458 & Not known* & Brazil & da Costa et (2019) \\
MAN2 & MN985120 & Melon & Turkey & This study \\
MAN22 & MN985121 & Gherkin & Turkey & This study \\
MAN25 & MN985122 & Melon & Turkey & This study \\
IZM7 & MN985123 & Gherkin & Turkey & This study \\
IZM36 & MN985124 & Melon & Turkey & This study \\
\hline \hline
\end{tabular}

*found in human stool samples

\section{Results}

A total of 59 cucurbit plants with viruses and viruslike symptoms were collected. Forty-nine of these were melon, seven were pumpkins, and three were gherkins. $\mathrm{CmEV}$ was detected in 47 of the samples (Table 3).

With the exception of five collected melon samples, nearly all were found to be infected with $\mathrm{CmEV}$. Three $\mathrm{CmEV}$ infections were detected in gherkin plants. CmEV infection was detected in none of the pumpkin plants.

As a result of the sequence analysis performed, it was determined that Turkish $\mathrm{CmEV}$ isolates showed 93\%$99 \%$ and $94 \%-99 \%$ identities with each other at the nucleotide and amino acid levels, respectively. In multiple sequence alignments with world $\mathrm{CmEV}$ isolates, it was observed that Turkish CmEV isolates showed 93\%-98\% and $91 \%-98 \%$ identities at the nucleotide and amino acids levels, respectively. The highest nucleotide identity rate between the Turkish and world $\mathrm{CmEV}$ isolates was found to be $98 \%$ between MAN25 with BRA/TO-74/2010 and BRA/TO-23/2014 isolates, while the least nucleotide identity was found to be $93 \%$ between MAN22 with CL01 and SJ1 isolates (Fig. 2).

Based on the phylogenetic analysis, all of the Turkish CmEV isolates, except MAN25 and IZM36, were closely related and formed a separate clade. While the world isolates form a clade with MAN25, IZM36 was found as a separate clade that consists of only itself (Fig. 3).

Table 3. The numerical distribution of the sampled cucurbits in each province. The numbers of infected samples were also given for each different plant.

\begin{tabular}{lccc}
\hline \hline & Manisa & Province & izmir \\
Cucurbit Species & $\begin{array}{c}\text { Iumber of Infected/Collected } \\
\text { Samples }\end{array}$ & $\begin{array}{c}\text { Total Number of } \\
\text { Number of Infected/Collected } \\
\text { Samples }\end{array}$ & $\begin{array}{c}\text { Infected and Collected } \\
\text { Samples }\end{array}$ \\
\hline \hline Melon & $24 / 24$ & $20 / 25$ & $44 / 49$ \\
Pumpkin & $0 / 1$ & $0 / 6$ & $0 / 7$ \\
Gherkin & $2 / 2$ & $1 / 1$ & $3 / 3$ \\
Total Number of & $26 / 27$ & $21 / 32$ & $47 / 59$ \\
\hline Infected/Collected Samples & & & \\
\hline
\end{tabular}
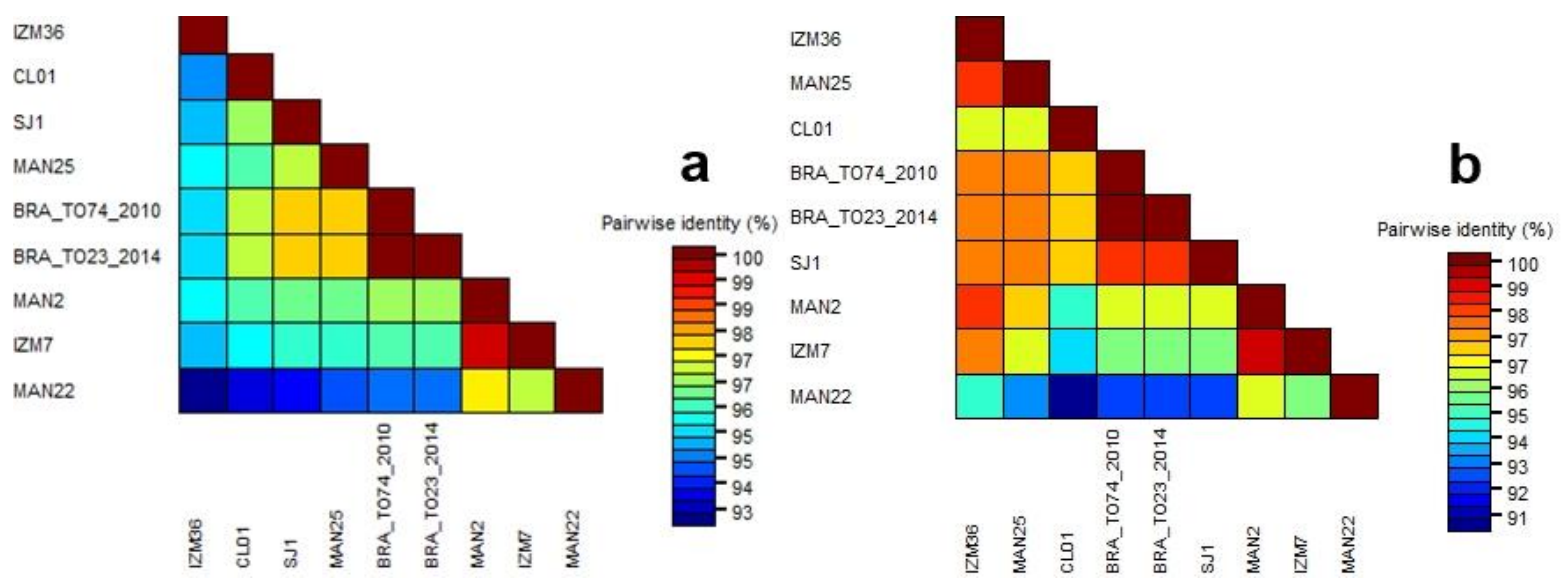

Fig. 2. Identity matrix of Turkish and world $\mathrm{CmEV}$. The colored identity matrix was generated by using partial polyprotein gene region of CmEV based on nucleotide (a) and amino acid (b) sequences. 


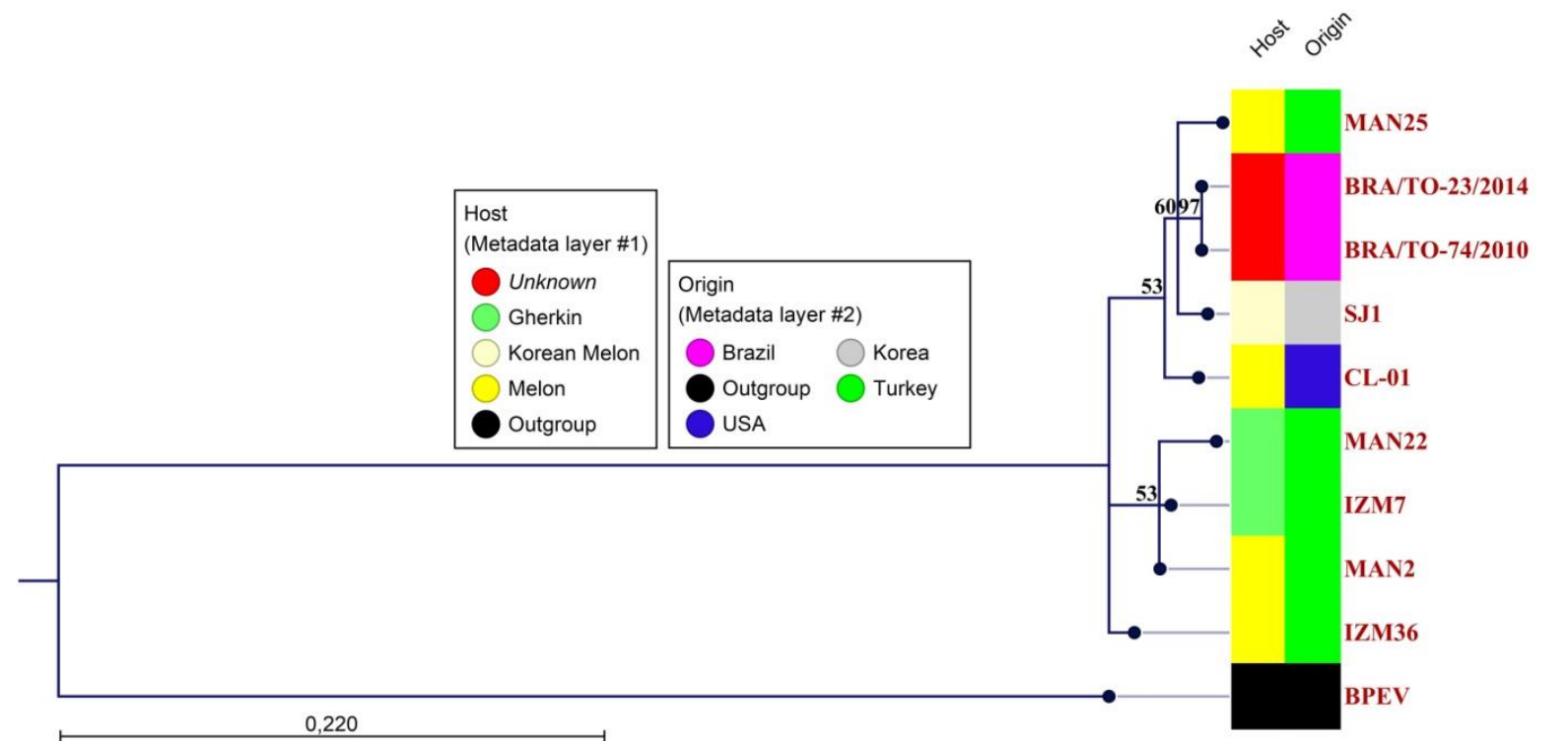

Fig. 3. Phylogenetic relationship of Turkish $\mathrm{CmEV}$ isolates based on the partial polyprotein gene region. The phylogenetic tree was generated by neighbor-joining method applying Kimura 80 parameters with 1000 bootstrap replications. The bootstrap threshold was implemented at 50\%. Bell pepper endornavirus (BPEV) was used as the outgroup.

\section{Discussion}

Although the presence of $\mathrm{CmEV}$ from different countries has been reported, only one study (Quito-Avila et al. 2014) about the prevalence of the causal agent comes to the forefront. As a result of this study conducted in cucurbit production fields in Ecuador, it was reported that $95 \%$ of melon plants with and without virus-like symptoms were infected with CmEV. No CmEV infection was detected in watermelon and cucumber plants (QuitoAvila et al. 2014). In this context, the results obtained in the present study were found to be in parallel with the results of Quito-Avila et al. (2014).

It is known that endornaviruses infect plants and fungi. There are many economically important crops that are infected with these viruses. Some of these crops are rice, barley, pepper, and common bean (Wakarchuk \& Hamilton 1985, Zabalgogeazcoa \& Gildow 1992, Fukuhara et al. 1993, Okada et al. 2011). In a recent study from the United States (US), endornaviruses were detected in non-cultivated plant species (Herschlag et al. 2019). In addition to the known host range of endornaviruses, gherkin was found to be a new host for $\mathrm{CmEV}$ as the result of this study.

In a study carried out in the US, it was reported that CmEV populations had $10 \%$ and $6 \%$ genetic variation

\section{References}

1. Baek, D., Lim, S. \& Moon J.S. 2016. First report of Cucumis melo endornavirus on Cucumis melo var. makuwa in Korea. https://www.ncbi.nlm.nih.gov/nuccore/KX641269 (Date accessed: 20 December 2019)

2. Çat, A., Yardımcı, N. \& Kılı̧̧, H.Ç. 2016. Identification of viral agents in the greenhouses in cucumber and pumpkin in Antalya province and counties. Süleyman Demirel with each other at the nucleotide and amino acid levels, respectively (Sabanadzovic et al. 2016). In this context, the identity rates obtained in this study showed great parallelism with that study.

It was determined that the isolates did not show phylogenetic distribution according to their geographic origin and host (Fig. 3). However, it is considered necessary to perform analyses using a much larger number of isolates with larger sequences for more reliable results.

As a result of the recent worldwide studies, the host range of endornaviruses has been expanded. However, the impact of these viruses on crop yields or growth parameters is still unclear (Escalante et al. 2016, Fukuhara 2019), especially in cases in which the CmEV infected plant is co-infected with severe viruses. To the best of our knowledge, this is the first report of $\mathrm{CmEV}$ with gherkin (C. anguria Linn.) as a new host both in Turkey and worldwide. Moreover, it is thought that the virus may present a more extensive worldwide distribution than previously reported.

\section{Acknowledgement}

This study was supported by a grant from The Scientific Research Coordination Unit of Çanakkale Onsekiz Mart University (project \# FBA-2019-2873).

University Journal of Natural and Applied Sciences, 20(1): 129-132.

3. da Costa, A.C., Leal, E., Gill, D., de Pádua Milagres, F.A., Komninakis, S.V., Brustulin, R., Teles, M.A.R, Lobato, M.C.A.B.S., das Chagas, R.T., Abrão, M.F.N.S., Soares, C.V.D.A., Delwart, X.D.E., Sabino E.C. \& Luchs, A. 2019. Discovery of Cucumis melo endornavirus by deep 
sequencing of human stool samples in Brazil. Virus Genes, 55(3): 332-338.

4. Escalante, C., Sela, N., Dombrovsky, A. \& Valverde, R. 2016. Interactions between bell pepper endornavirus, bell pepper, and acute plant viruses. In Proceedings of XVIth EUCARPIA Capsicum and Eggplant Working Group Meeting in Memoriam Dr. Alain Palloix, Kecskemét, Hungary, 231-237.

5. Fukuhara, T., Moriyama, H., Pak, J.K., Hyakutake, T. \& Nitta, T. 1993. Enigmatic double-stranded RNA in Japonica rice. Plant Molecular Biology, 21(6): 1121-1130.

6. Fukuhara, T., Koga, R., Aoki, N., Yuki, C., Yamamoto, N., Oyama, N., Udagawa, T., Horiuchi, H., Miyazaki, S., Higashi, Y., Takeshita, M., Ikeda, K., Arakawa, M., Matsumoto, N. \& Moriyama, H. 2006. The wide distribution of endornaviruses, large double-stranded RNA replicons with plasmid-like properties. Archives of Virology, 151(5): 995-1002.

7. Fukuhara, T. 2019. Endornaviruses: persistent dsRNA viruses with symbiotic properties in diverse eukaryotes. Virus Genes, 55(2): 165-173.

8. Herschlag, R., Escalante, C., de Souto, E.R., Khankhum, S., Okada, R. \& Valverde, R.A. 2019. Occurrence of putative endornaviruses in non-cultivated plant species in South Louisiana. Archives of Virology, 164(7): 1863-1868.

9. Jeffrey, C. 1980. A review of the Cucurbitaceae. Botanical Journal of the Linnean Society, 81(3): 233247.

10. Kamberoglu, M.A., Caliskan, A.F. \& Desbiez, C. 2016. Current status of some cucurbit viruses in Çukurova region (Adana and Mersin provinces) of Turkey and molecular characterization of zucchini yellow mosaic virus isolates. Romanian Biotechnological Letters, 21(4): 11709-11719.

11. Kaya, A. \& Erkan, S. 2011. Detection and incidence of viruses in cucurbits grown in Izmir, Aydın, Manisa and Balıkesir provinces. Plant Protection Bulletin, 51(4): $387-$ 405.

12. Keçe, M.A. \& Kamberoğlu, M.A. 2016. Biological, serological and molecular detection of watermelon mosaic virus (WMV-2) in watermelon growing fields in Eastern Mediterranean region. Journal of Tekirdag Agricultural Faculty, 13(03): 156-164.

13. Köklü, G. \& Yilmaz, Ö. 2006. Occurrence of cucurbit viruses on field-grown melon and watermelon in the Thrace region of Turkey. Phytoprotection, 87(3): 123-130.

14. Li, R., Mock, R., Huang, Q., Abad, J., Hartung, J. \& Kinard, G. 2008. A reliable and inexpensive method of nucleic acid extraction for the PCR-based detection of diverse plant pathogens. Journal of Virological Methods, 154(1-2): 48-55.

15. Muhire, B.M., Varsani, A. \& Martin, D.P. 2014. SDT: A virus classification tool based on pairwise sequence alignment and identity calculation. PLoS One, 9: 0108277.

16. Okada, R., Kiyota, E., Sabanadzovic, S., Moriyama, H., Fukuhara, T., Saha, P., Roossinck, M.J., Severin, A. \& Valverde, R.A. 2011. Bell pepper endornavirus: molecular and biological properties and occurrence in the genus Capsicum. Journal of General Virology, 92(11): 26642673.

17. Ozaslan, M., Aytekin, T., Bas, B., Kilic, H., Afacan, I.D. \& Dag, D.S. 2006. Virus diseases of cucurbits in Gaziantep, Turkey. The Plant Pathology Journal, 5(1): 24-27.

18. Quito-Avila, D.F., Peralta, E.L., Martin, R.R., Ibarra, M.A., Alvarez, R.A., Mendoza, A., Insuasti, M. \& Ochoa, J. 2014. Detection and occurrence of melon yellow spot virus in Ecuador: an emerging threat to cucurbit production in the region. European Journal of Plant Pathology, 140(2): 193197.

19. Sabanadzovic, S., Wintermantel, W.M., Valverde, R.A., McCreight, J.D. \& Aboughanem-Sabanadzovic, N. 2016. Cucumis melo endornavirus: genome organization, host range and co-divergence with the host. Virus Research, 214: $49-58$.

20. Topkaya, S., Desbiez, C. \& Ertunc, F. 2019. Presence of cucurbit viruses in Ankara and Antalya province and molecular characterization of coat protein gene of zucchini yellow mosaic virus Turkish isolates. Fresenius Environmental Bulletin, 28(4): 2442-2449.

21. Valverde, R.A., Khalifa, M.E., Okada, R., Fukuhara, T., \& Sabanadzovic, S. 2019. ICTV virus taxonomy profile: Endornaviridae. Journal of General Virology, 100(8): 1204-1205.

22. Wakarchuk, D.A. \& Hamilton, R.I. 1985. Cellular doublestranded RNA in Phaseolus vulgaris. Plant Molecular Biology, 5(1): 55-63.

23. Zabalgogeazcoa, I.A. \& Gildow, F.E. 1992. Doublestranded ribonucleic acid in 'Barsoy' barley. Plant Science, 83(2): 187-194.

24. Zitter, T.A., Hopkins, D.L. \& Thomas, C.E. 1996. Compendium of Cucurbit Diseases. The American Phytopathological Society Aps Press, St. Paulk, Minesota, $87 \mathrm{p}$. 